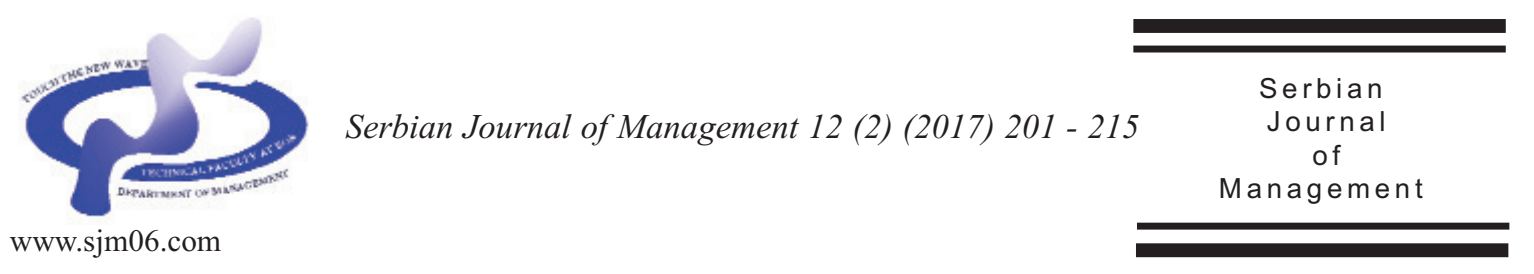

\title{
HOW TO PERCEIVE THE CORPORATE SOCIAL RESPONSIBILITY IN THE AGRO-FOOD COMPANIES?
}

\author{
Iveta Ubrežiová* and Kamila Moravčíková \\ Faculty of Economics and Management, Slovak University of Agriculture in Nitra \\ Tr. A. Hlinku 2, 94976 Nitra, Slovakia
}

(Received 23 June 2016; accepted 15 November 2016)

\begin{abstract}
The basic aim of the article is to evaluate the extent of a companies' engagement with CSR as well as to uncover the nature and type of CSR activities in the agro-food companies operating in the Slovak Republic. In order to fulfill the basic aim, we set the partial aims which involve several research questions. Primary information and data were obtained by the questionnaire survey in order to assess the level of companies' engagement with CSR policy and activities they carry out within this policy. Secondary data consist of various publications, web-pages of selected companies, their annual general statements and statements concerning CSR policy. To every company, one questionnaire was distributed - in some case, it was possible to send it directly to person responsible for CSR activities. To graphically display our results, we used MS Excel and for other statistical processing SAS and SPSS. According to the results and findings from the questionnaire survey, the authors of the article finds it appropriate to offer several recommendations and ideas dealing with support of CSR in the Slovak Republic.
\end{abstract}

Keywords: networking, entrepreneurs' network, innovative entrepreneurship, small and medium sized enterprises

\section{INTRODUCTION}

Corporate Social Responsibility and its implication in the agro-food companies located in the Slovak Republic. Since 1990s, there has been a very big change in the relationship between business and society.
When speaking about this change, several factors have contributed to it, such as globalization, deregulation, increased size of companies and many others. As a consequence of globalization, the whole world is more interdependent and multinational corporations have become the

\footnotetext{
* Corresponding author: iubreziova@gmail.com
}

DOI: $10.5937 /$ sjm12-11229 
main drivers of this phenomenon as they support international trade, growth and development. In the Slovak Republic, there is not much literature concerning CSR as in the European context it has spread just in recent years. Since that time, Slovakia has undergone a huge progress what is visible by looking at the development of macroeconomic indicators. There is a lack of understanding of the CSR among public and business sector and thus, it is one of the aims of the thesis to provide general overview of the literature dealing with CSR. Concept of CSR plays an important role in this environment and represent a great opportunity for companies to become successful while also making world a better place. Formal writings on social responsibility are basically a product of the $20^{\text {th }}$ century, more precisely the product of the past 50 years. The corporate social responsibility of companies trying to enter new markets in relation to rural development and internationalize their production is a hot topic, nowadays. The understanding and implementation of CSR concept from the viewpoint of business strategy for small and medium-sized enterprises. Especially in Europe, where $99 \%$ of business companies are SMEs, focus is devoted into more structured implementation of CSR concept into SMEs business strategies (Ubrežiová \& Horská, 2011). The same opinion have the authors Mura and Gašparíková (2010) and Ubrežiová et al. (2013).

\subsection{Corporate Social Responsibility in Agribusiness}

Following Heyder and Theuvsen (2012), agribusiness in Europe has been recently influenced by many crises and conflicts. Many important international organizations have released standards dealing with CSR as well. What does it mean for the companies? They have to face new challenges and also try to find ways how to integrate CSR into their activities and operations (Dahlsrud, 2008). Although in the economy all sectors have to deal with growing demand about CSR, its position in food and agriculture sector is very special. One may ask, why is that so? The answer is very simple - the causes are food security and health issues. Public has always felt and pushed the governments to control the food system and its aspects (Poetz et al., 2012). Following Hartmann (2011), food sector in the EU is heterogeneous what causes that actors in the food chain face different level of pressure. Moreover, no other sector is so highly dependent on natural resources, while at the same time having considerable and diverse impact on environment (Maloni \& Brown, 2006). However, difference between industries is not the only factor where the pressure on companies to implement CSR varies - it is also different within the industry. The bigger the company, the higher is the request of society for company to implement the CSR. Therefore, the size seems to be crucial factor (Hartmann, 2011). For large companies, reporting, communicating or advertising CSR are very essential factors while SMEs and micro companies tend not to communicate CSR so much. Even if they do - it is usually unsystematic and localized (Murillo \& Lozano, 2006). It is possible to say that there are only few parts of the food value chain that are not criticized. On the other hand, the majority of those parts have to face criticism for many reasons. Mazur-Wierzbicka (2015) states that growing consumers' criticism of agricultural activities and agribusiness is a result of increasing ecological awareness and 
understanding the need to consider social and ecological perspectives. Usually, mostly discussed are "negative externalities of food production and moral concerns" (Heyder \& Theuvsen, 2012), the use of genetically modified organisms (GMOs). When speaking about GMOs, at least European society considers its use as unethical practice by society (Koppelmann \& Willers, 2008). Other industries, such as food and beverage one, have to deal with issues related to health - such alcohol abuse, obesity and others (Schäfer Elinder et al., 2006). Companies have had to face exposed scandals, for example in meat industry what have led to further consequences. According to Albersmeier and Spiller (2010) and Hajdu et al. (2014), it generally means that companies in agriculture and food industry (with focus on specific subsectors) have very weak reputation. As mentioned above, position of agribusiness is different than the position of other industries, mainly due to its diversity. Smith and Feldman (2004) consider the diversity and less CSR drivers as the reason why standards exist for different products, regions and even production methods. However, Barrientos et al. (2003) confirm that within the food chains, the amount of corporate codes and other standards has grown significantly over the past years. Many stakeholders in the food sector are more and more interested in CSR and how the business affects the society and environment (Deblonde et al., 2007; Lamberti \& Lettieri, 2009; Maloni \& Brown, 2006). They have growing demand for food that is healthier, safer and more environmentally or animal friendly (Gao et al., 2010; Krasnodebski \& Cieslik, 2001; Matysek-Pejas \& Szafranska, 2009). Derived from these facts, it is visible that food companies consider the responsibility as key issue and sometimes as a source of competitive advantage (Heikkurinen \& Forsman-Hugg, 2011). Altogether, that are not many authors who dedicate their attention to study CSR in food industry. For example Maloni and Brown (2006) researched CSR within food supply chain. Moreover, they distinguished eight categories in CSR framework for this sector: health and safety, animal welfare, biotechnology, community, environment, financial practices, labor and procurement. In spite of specific position of companies in food sector, CSR policy has become an essential part and basis for companies within agribusiness (Dlott et al., 2006).

\section{METHODOLOGY}

The basic aim of this paper is to evaluate the extent of a companies' engagement with CSR as well as to uncover the motives and barriers the agro-food companies operating in the Slovak Republic face to. Primary information and data were obtained by the questionnaire survey in order to assess the level of companies' engagement with CSR policy and activities they carry out within this policy.

To every company (81 companies) one questionnaire was distributed - in some cases, it was possible to send it directly to person responsible for CSR activities, but mostly we used general e-mail addresses. Based on the demographic structure, the respondent's structure consists from $75 \%$ (61) of men and $25 \%$ (20) of women. However, in the accompanying letter and also in the introduction of the questionnaire, we stressed out to whom the questionnaire should be passed to (person responsible for CSR, managing director, HR manager). 
Secondary data consist of various publications, web-pages of selected companies, data from Statistical Office of the Slovak Republic/Ministry of Agriculture and Rural Development/National Bank of Slovakia, and statements concerning CSR policy. As mentioned above, the primary data obtained from questionnaire survey as well as secondary data were processed by the use of mathematical and statistical methods. To graphically display our results, we used MS Excel and for other statistical processing SAS and SPSS. Following methods and tests were applied:

- Content and Document Analysis

- Cronbach alpha coefficient

- Chi Square Tests

- Kruskal - Wallis H test

- $\quad$ Multiple Range Tests - Fisher LSD Test.

Since five areas of the questionnaire consists of scaling questions, it was necessary to evaluate their internal consistencies. Table 1 displays results achieved in each area.

Table 1. Cronbach Alpha Values for Evaluated Questionnaire

\begin{tabular}{lc}
\hline Area & Value of Cronbach Alpha \\
\hline Motivation factors & 0.892 \\
Environmental pillar & 0.874 \\
Policy at the workplace & 0.816 \\
Policy towards community & 0.732 \\
Economic pillar & 0.824 \\
Totally & 0.925 \\
\hline Source: Own processing &
\end{tabular}

Altogether, 81 companies took part in the survey. The whole questionnaire was divided into 7 main areas - general information about the companies, management of CSR, activities in policy (environmental, towards community, at the workplace, economic), and concluding questions.

\subsection{Chi Square Test for Independence}

The test for independence is quite different from goodness of fit test - while the test of goodness of fit is concerned only with one variable, the independence test examines the relationship between two variables. It is used to verify existence of dependence between qualitative characteristics. The equation is similar to previous one, and it is calculated as following:

$$
\chi^{2}=\sum_{i=1}^{m} \sum_{j=1}^{k} \frac{\left(O_{i j}-E_{i j}\right)^{2}}{E_{i j}}
$$

Where:

$\chi^{2}=$ Chi-square Independence Test Statistic, with chi square distribution $(\mathrm{m}-1) .(\mathrm{k}-1)$ degree of freedom,

$O_{i j}=$ the observed frequency count of the categorical variable observed in the $i$ th row and $j$ th column,

$E_{i j}=$ the expected frequency count of the categorical variable in the $i$ th row and $j$ th column,

$m=$ number of rows,

$k=$ number of columns.

Table 2. Chi-Square Test for Independence (Size vs. CSR linkage to business strategy)

\begin{tabular}{llll}
\hline Statistic & DF & Value & Prob. \\
\hline Chi-Square & 12 & 15.0085 & 0.2410 \\
Likelihood Ratio Chi-Square & 12 & 14.4122 & 0.2752 \\
Mantel-Haenszel Chi-Square & 1 & 0.2953 & 0.5869 \\
Phi Coefficient & & 0.4331 & \\
Contingency Coefficient & & 0.3975 & \\
Cramer's V & 0.2501 & \\
\hline
\end{tabular}

Source: Results from SAS processing

\subsection{Kruskal-Wallis H Test}

This test, named by its authors, is nonparametric test used to determine 
significance of differences in mean values for more than two independent groups (Kruskal \& Wallis, 1952). It is used when assumptions of ANOVA are not met. The test requires that all observations are ranked together and there is a sum of the rank for each sample. To verify the $\mathrm{H} 0$ hypothesis, which assumes there are no difference in mean values within the group, the following relationship was used:

$H=\frac{12}{N(N+1))} \cdot \frac{\sum_{j=1}^{n} R_{j}^{2}}{n_{j}}-3(N+1)$

Where:

$H=$ Kruskal-Wallis Test Statistic,

$R_{j}=$ the sum of the ranks in the $j$-th sample, $n_{j}=$ the number of observation in the $j$-th sample,

$N=\sum \mathrm{n}_{\mathrm{j}}$, the number of observations in all samples combined.

Interpretation of the results is based on the calculation the Kruskal - Wallis test. After testing, we obtain the required test value $p-$ value on the selected level of significance $95 \%=0.05$. In the case that $p-$ value $<0.05$, $\mathrm{H} 0$ hypothesis is rejected and we accept $\mathrm{H} 1$ hypothesis, which implies that there are significant differences at least between one pair of mean values within the test group. In the case that $p-$ value $\geq 0.05, \mathrm{H} 0$ hypothesis accepted. Thus, the differences between each pair of the mean values may be the result of random sampling and are not statistically significant. Therefore, following hypotheses were formulated between CSR and business strategy - $\boldsymbol{H}_{\boldsymbol{0}}$ : Size of the company is related to the extent of linkage between CSR and business strategy.; and $\boldsymbol{H}_{1}$ : Size of the company is related to the extent of linkage between CSR and business strategy. ${ }^{1}$

In relation to the factors motivating the companies to implement CSR following hypotheses were tested - $\boldsymbol{H}_{\boldsymbol{0}}$ : Differences in the extent of factors motivating the companies to implement CSR are not statistically significant.; and $\boldsymbol{H}_{\boldsymbol{1}}$ : Differences in extent of factors motivating the companies to implement CSR are statistically significant. The similar hypotheses and results of their verification were obtained by Nagyová at al. (2016) and Ubrežiová et al. (2015).

\section{RESULT AND DISCUSSION}

To start gaining an understanding of CSR in agro-food companies in Slovakia, the first question focuses on identification of respondents' familiarity with the term CSR. When filling the questionnaire, respondents were asked whether they have heard about CSR before getting the questionnaire. Out of 81 surveyed companies, almost half of them claims they know the concept (41\%) and the rest $(59 \%)$ states they have not heard about it. The previous surveys on this topic focused on the companies operating in Slovakia show, that the level of knowledge about CSR moves around $50 \%$. In the research done by FOCUS (2010), that was oriented on SMEs, $52 \%$ companies claimed they know the concept. In her paper, Jad'ud'ová (2013) focused on companies of all sizes and stated that almost half of the surveyed companies knows CSR as well. The lowest share of respondents familiar with CSR concept was noted in the survey done by Ubrežiová et al. (2013) - although it was focused on companies in Eastern Slovakia, only 34\% of

\footnotetext{
${ }^{1}$ As it is displayed above, the question dealing with relation of CSR and business strategy is of scaling type. It may cause the hypotheses are formulated bit more complicated. In order to understand them clearly, following explanation is offered: the second part of hypotheses $\mathrm{H}_{0}$ and $\mathrm{H}_{1}$ (the extent of linkage between CSR and business strategy) is considered as one variable.
} 
companies claimed familiarity with CSR. One may argue that it is not reasonable to compare the results of this research with others since they were mostly oriented on SMEs. In Slovakia, however, around 99\% of companies belong to the category of SMEs. In the case of agro-food companies studied in this paper, the familiarity with the CSR is somewhere between the previous surveys. Since many studies point out that CSR is part of the business strategy mostly in the case of large companies, while SMEs provide them on ad-hoc basis (Jenkins, 2006; Joyner \& Payne, 2002; Schaper \& Savery, 2004) we decided to verify if this is the same for the surveyed agro-food companies in Slovakia. The obtained data were tested in SAS. As it is displayed in the table below, p-value is higher than 0,05 (p-value $>0,05$ at confidence level $\alpha=95 \%$ ), therefore, $\mathrm{H} 0$ is not rejected. It implies that size does not affect the extent to which CSR is connected with business strategy. Still, it should be noted that prevailing majority of respondents was SMEs what may cause such statistical results.

In order to uncover the nature of CSR management in agro-food companies, surveyed companies were asked to specify the person or the department responsible for CSR activities within the company. Along with this, the connecting question dealing with the length of time of existence of such position/department was formulated and respondents indicated for how long this positon/department is in place. Firstly, the respondents were asked to write down who is responsible for CSR activities. Analysis shows that in most cases (almost 36\%) there is no one - no position or department. In the case company has such person, it is usually the executive manager (around 23\%) or chairman of the cooperative $(21 \%)$. Since one third of the companies indicated there is no such position or department, it can be assumed that this portion of the companies does not implement CSR activities. There was no answer suggesting there exists particular department or position directly related to CSR. Besides executive manager and chairman of the cooperative, following positions were mentioned - owner, CEO, production director, sales director, marketing manager, QM manager, director for external relations, statutory representative, enologist and HACCP officer. Thus, variety of positions is pretty wide what implies different opinions of surveyed companies on who should be responsible for CSR. Since most of the companies is SMEs, their small size allows them to select the person that fits the position the best and take into account particular specifics of the companies.

Table 3. Existence of Person/Department Responsible for CSR

\begin{tabular}{lll}
\hline $\begin{array}{l}\text { Person/Department } \\
\text { responsible for CSR }\end{array}$ & $\begin{array}{l}\text { Absolute } \\
\text { number }\end{array}$ & $\begin{array}{l}\text { Relative number } \\
\text { (in \%) }\end{array}$ \\
\hline No one & 29 & 35.8 \\
Executive manager & 19 & 23.5 \\
Chairman & 9 & 11.1 \\
Owner & 7 & 8.6 \\
Other & 17 & 21 \\
Totally & 81 & 100.0 \\
\hline
\end{tabular}

Source: Own processing

Generally known, the CSR concept is relatively new in Slovakia. Therefore, we were curious about the formal side and the length of its involvement in management structures. Following question was formulated in order to specify the length of time such position is in place. All three large companies undertaking the survey indicated they have appointed a person responsible for CSR activities - in two of them, this position has been in place for more than 5 years and in one for 2 to 5 years. Three out of four 
companies owned by foreign investor claimed there is a person responsible for CSR. Interesting is the fact that the only company in the survey with the status of MNE subsidy claimed that such position exists only for 2 to 5 years, although the company has been operating in Slovakia for at least ten years. It is possible to notice certain inconsistency with previous results. Firstly, almost $36 \%$ declared there is no one responsible for CSR, although above it is indicated that $63 \%$ of companies do not have position/department responsible for CSR. This may be caused by different opinions how to understand the question. Some of the companies may think it is meant in terms of formal management structures and on the other hand, some may understand it an informal assignment of responsibilities.

Since this area consists of scaling questions, it was necessary to test reliability of scaling by Cronbach Alpha Coefficient. As it is displayed above, very good level of internal consistency was achieved. Based on the obtained results and primary analysis, it is visible that respondents agreed on some factors to higher extent and in others to much lesser extent. Therefore, it was analyzed whether such differences in the answers of the respondents are statistically significant or not. After the calculations, the results of Kruskal-Wallis $\mathrm{H}$ Test gave us following value: $p$-value $=1,0984 \mathrm{E}-9$. Such $p$-value means ( $p$-value $<0.05$ at confidence level $\alpha$ $=95 \% ; p$-value $<0.01$ at confidence level $\alpha$ $=99 \%$ ) that $\mathrm{H} 0$ is rejected. Therefore, the differences in the extent of the factors motivating the companies to implement CSR are statistically highly significant. According to its results, there are four homogenous groups of factors motivating the companies to undertake CSR. Statistical testing confirms primary analysis mentioned at the beginning of this chapter. Factors were divided into four homogenous groups, ranked by the extent to which they motivate companies to implement CSR (some activities can be assigned to two groups).

Table 4. Kruskal Wallis H Test (Factors Motivating Companies to Implement CSR)

\begin{tabular}{lcc}
\hline \multicolumn{1}{c}{ Factors } & $\begin{array}{c}\text { Sample } \\
\text { Size }\end{array}$ & $\begin{array}{c}\text { Average } \\
\text { Rank }\end{array}$ \\
\hline $\begin{array}{l}\text { Ethical and moral } \\
\text { reasons }\end{array}$ & 81 & 370,623 \\
$\begin{array}{l}\text { To increase economic } \\
\text { performance }\end{array}$ & 81 & 403,142 \\
$\begin{array}{l}\text { To improve relations } \\
\text { with suppliers/investors }\end{array}$ & 81 & 395,951 \\
$\begin{array}{l}\text { To improve community } \\
\text { relations }\end{array}$ & 81 & 317,586 \\
$\begin{array}{l}\text { To maintain/increase } \\
\text { company's reputation }\end{array}$ & 81 & 444,407 \\
$\begin{array}{l}\text { To increase motivation } \\
\text { of employees }\end{array}$ & 81 & 353,173 \\
$\begin{array}{l}\text { A commitment to } \\
\text { protect environment }\end{array}$ & 81 & 383,080 \\
$\begin{array}{l}\text { Pressure from third } \\
\text { parties (competitors, } \\
\text { clients, ...) }\end{array}$ & & \\
$\begin{array}{l}\text { To maintain/increase } \\
\text { loyalty of the customers }\end{array}$ & 81 & 240,735 \\
\hline $\begin{array}{l}\text { Test statistic = 58,0992 } \\
\text { P-value = 1,0984E-9 }\end{array}$ & & 376,302 \\
\hline
\end{tabular}

Source: Own processing

The most motivating factor is definitely to increase company's reputation. Second group of activities consists of three motivating factors (that motivate companies to little bit lower extent) - increase of economic performance, improving the relations with the suppliers/investors and commitment to protect environment. Thirdly, there are three factors as well - maintaining the loyalty of customer, ethical and moral reasons and increasing the motivation of employees. The last group contains only one factor that motivates companies to the lowest extent - pressure from third parties. The 
results of our survey are in line with other publications, too. McWilliams et al. (2006) claim that it is possible to consider CSR as strategic investment or as a way how to increase financial performance (Barnett \& Salomon, 2012). In the literature, increase of profitability is connected to large companies (Prinic, 2003), while SMEs consider ethical reasons as one of the main motivators (Jenkins, 2006). Customer loyalty was considered as strong factor for motivation for almost $40 \%$ of companies in our research, what is in line with the argument of Bhattacharya and Sen (2001). When taking into account surveys in Slovakia, the biggest motivational factor according to FOCUS (2010) was keeping up with the competition, followed by attracting and retaining quality employees.

\section{CONCLUSION}

When discussing CSR in Slovakia, the overall situation is not very optimistic and the rate of CSR knowledge is pretty low. Previous surveys conducted on CSR in Slovakia indicates that the level of familiarity with the term CSR moves around half of the surveyed companies (FOCUS, 2010; Jad'ud'ová, 2013; Ubrežiová et al., 2013). In comparison with current state of CSR within the Czech Republic, there are not huge differences. In surveys realized in the last 10 years, the rate of knowledge about CSR was almost the same. Following the BLF survey, it was about 47\% (BLF, 2008) what is the same level as in the survey done by Skýpalová and Kučerová (2015). Little bit higher percentage of respondents (56\%) indicated familiarity with CSR in the survey of Kunz (2012). Its development within agro-food companies more or less copies situation in the overall economy sector in Slovakia, since $42 \%$ of respondents are familiar with this concept. However, this result does not imply that agro-food companies do not behave socially responsible or apply CSR principles. It may just suggest that implementation of CSR principles is relatively new topic on the management agenda of agro-food companies. Almost all of the surveys conducted in Slovakia were aimed on SME. This does not correspond to the global trend, where most of the literature dealing with CSR is concerned about MNEs and SMEs remain at the margin (Joyner \& Payne, 2002; Perrini \& Minoja, 2008). The results of our survey show, that more than two thirds of companies $(64.3 \%)$ strongly agree or agree that principles of CSR are closely related to their business strategy. Based on the theoretical suggestions, the authors of the paper verified if there exists a difference between SMEs and large companies in relation to integration CSR into the business strategy. Firstly, the results of the survey show that there is statistically significant relationship between existence of the strategy and size of the company. It was mostly small companies ( $10-49$ employees) that tend to has defined strategy. Then, the authors analyzed the core problem however, statistical testing suggests that size does not affect the extent to which the CSR is connected with business strategy. Still, it should be noted that prevailing majority of respondents were SMEs what may cause such statistical results. Szekely and Knirsch (2005) argue that lack of integration of CSR and business strategy may be a barrier to implement CSR principles. 


\title{
КАКО РАЗУМЕТИ КОРПОРАТИВНУ ДРУШТВЕНУ ОДГОВОРНОСТ У КОМПАНИЈАМА АГРО-ХРАНЕ ?
}

\author{
Iveta Ubrežiová, Kamila Moravčíková
}

\section{Извод}

Основни циљ овог рада је да процени ниво учешћа компанија у корпоративној друштвеној одговорности (КДО), као и да процени природу КДО акција у компанијама агро-хране, које раде у Словачкој Републици. Како би се испунио осовни циљ, поставњени су парцијални циљеви који су укључивали неколико истраживачких питања. Примарне информације и подаци су сакупљани упитником како би се проценио ниво укључења компаније у КДО акције, које спроводе у овкиру своје пословне политике. Секундарни подаци се састоје од бројних публикација, интернет страница одабраних компанија, њихових годишњих извештаја и извештаја који се односе на политику КДО. По један упитник је упућиван свакој компанији. У неким случајевима, било је могуће да се пошању директно особи која је одговорна за КДО активности. Како би се графички представили добијени резултати, коришћен је МС ексел и други статистички софтвер, као што је САС и СПСС. На основу добијених резултата, аутори су понудили неколико предлога и идеја које подржавају област КДО у Словачкој Републици.

Кључне речи: Умрежавање, мреже предузетника, иновативно предузетиништво, мала и средња предузећа

\section{References}

Albersmeier, F., \& Spiller, P. (2010). The reputation of the German meat sector: A structural equation model. German Journal of Agricultural Economics, 59, 258-270.

Barrientos, S., Dolan, C. \& Tallontire, A. (2003). A Gendered Value Chain Approach to Codes of Conduct in African Horticulture. World Development, 31 (9), 1511-1526.

Barnett, M.L., \& Salomon, R.M. (2012). Does it pay to be really good? Addressing the shape of the relationship between social and financial performance. Strategic Management Journal, 33 (11), 1304-1320.

Bhattacharya, C.B., \& Sen, S. (2001). Does doing good always lead to doing better? Consumer reactions to corporate social responsibility. Journal of Marketing Research, 38, (2), 225-243.

Dahlsrud, A. (2008). How Corporate
Social Responsibility is Defined: an Analysis of 37 definitions. Corporate Social Responsibility and Environmental Management, 15, 1-13.

Deblonde, M., De Graaf, R., \& Brom, F. (2007). An Ethical Toolkit for Food Companies: Reflections on Its Use. Journal of Agricultural and Environmental Ethics, 20, 99-118.

Dlott, J., Gunders, D., \& Arnold, A. (2006). Sustainability Trends in the Agrifood Sector. Sure Harvest Briefing Paper. Soquel, UK: Sure Harvest.

FOCUS. (2010). Perception of the CSR concept and its practiques by SMEs in Slovakia. [Online] FOCUS. [Accessed 201512-21]. Available at WWW: $<$ www.sbagency.sk/sites/default/files/sprava _csr_sme.pdf> (In Slovak)

Gao, Z., Schroeder, T., \& Yu, X. (2010). Consumer willingness to pay for cue 
attribute: The value beyond its own. Journal of International Food \& Agribusiness Marketing, 22, 108-124.

Hajdu, Z., Andrejkovič, M., \& Mura, L. (2014). Utilizing experiments designed results during error identification and improvement of business processes. Acta Polytechnica Hungarica, 11 (2), 149-166.

Hartmann, M. (2011). Corporate social responsibility in the food sector. European Review of Agricultural Economics, 38 (3), 297-485.

Heikkurinen, P., \& Forsman-Hugg, S. (2011). Strategic corporate responsibility in the food chain. Corporate Social Responsibility and Environmental Management, 18 (5), 306-316.

Heyder, M., \& Theuvsen, L. (2012). Corporate Social Responsibility in German Agribusiness. Agribusiness, 28 (4), 400-420.

Jad'ud'ová, J. (2013). Perception of Corporate Social Responsibility in selected sector of national economy of the Slovak Republic. Electronic International Interdisciplinary Conference, 2, 339-342.

Jenkins, H. (2006). Small Business Champions for Corporate Social Responsibility. Journal of Business Ethics, $62,241-256$.

Joyner, B., \& Payne, D. (2002). Evolution and Implementation: A Study of Values, Business Ethics and Corporate Social Responsibility. Journal of Business Ethics, 41 (4), 297-311.

Koppelmann, U., \& Willers, C. (2008). Marketing in resistance markets. Absatzwirtschaft-Zeitschrift fur Marketing, 2, 28-32. (In German)

Krasnodebski, A., \& Cieslik, J. (2001). Studies on consumer preferences on an example of dairy products. Proceedings of scientific papers III - Competitiveness of Selected Agrarian Commodities of Slovakia
Before its Accession to the EU, SUA in Nitra. 53-57.

Kruskal, W.H., \& Wallis, A.W. (1952). Use of Ranks in One-Criterion Variance Analysis. Journal of the American Statistical Association, 47 (260), 583-621.

Kunz, V. (2012). Corporate social responsibility, Grada Publishing, a.s., Praha, 208. (In Czech)

Lamberti, L., \& Lettieri, Em. (2009). CSR Practices and Corporate Strategy: Evidence from a Longitudinal Case Study. Journal of Business Ethics, 87, 153-168.

Maloni, J.M., \& Brown, M.E. (2006). Corporate Social Responsibility in the Supply Chain: An Application in the Food Industry. Journal of Business Ethics, 67, 3552.

Matysek-Pejas, R., \& Szafranska, M. (2009). European consumer and products of ecological agriculture. In Horská E.: European consumer and consumer behavior SPU, Nitra, 174-193. (In Slovak)

Mazur-Wierzbicka, E. (2015). The application of Corporate Social Responsibility in European Agriculture. Moscellanea Geographica - Regional Studies on Development, 19 (1), 19-23.

McWilliams, A., Siegel, D., \& Wright, P. (2006). Corporate social responsibility: strategic implications. Journal of Management Studies, 43 (1), 1-18.

Murillo, D., \& Lozano, J.M. (2006). SMEs and CSR: an Approach to CSR in their own words. Journal of Business Ethics, 67, 227-240.

Mura, L., \& Gašparíková, V. (2010). Penetration of Small and Medium Sized food companies on foreign markets. Acta Universitatis Agriculturae et Silviculturae Mendeleianae Brunensis, 58 (3), 157-163.

Nagyová, L', Holienčinová, M., Košičiarová, I., \& Holota, T. (2016). 
Corporate Social Responsibility in food manufacturing companies - environmental dimensions. In: Acta Universitatis Agriculturae et Silviculturae Mendeliannae Brunensis. 64 (3), 1037-1043.

Perrini, F., \& Minoja, M. (2008). Strategizing Corporate Social Responsibility Evidence from an Italian Medium Sized Family Owned Company. Business Ethics: A European Review, 17 (1), 47-63.

Poetz, K., Haas, R., \& Balzarova, M. (2012). Emerging strategic corporate social responsibility partnership initiatives in agribusiness: the case of the sustainable agriculture initiative. Journal on Chain and Network Science, 12 (2), 151-165.

Prinic, L. (2003). Engaging Small Business in Corporate Social Responsibility. Canadian Business for Social Responsibility: Canada.

Schaper, M., \& Savery, L. (2004). Entrepreneurship and Philanthropy: The Case of Small Australian Firms. Journal of Development Entrepreneurship, 9 (3), 239250.

Schäfer Elinder, L., Lock K., \& Blenkus, G.M. (2006). Public health, food and agriculture policy in the European Union. T. Stahl et al. (Eds.), Health in all policies. Prospects and potentials. Helsinki: Ministry of Social Affairs and Health and European Observatory on Health Systems and Policies.

Smith, G., \& Feldman, D. (2004). Implementation mechanisms for codes of conduct. CSR Practice, Foreign Investment Advisory Service, Investment Climate Department. World Bank and International Finance Corporation, Washington DC, USA, 2004.

Skýpalová, R., \& Kučerová, R. (2015). Knowledge and Application of Concept of the Corporate Social Responsibility in the Czech Republic. Procedia Economics and
Finance, 12, 607-615.

Szekely, F., \& Knirsch, M. (2005). Responsible Leadership and Corporate Social Responsibility: Metrics for Sustainable Performance. European Management Journal, 23 (6), 628-647.

Ubrežiová, A., \& Horská, E. (2011). Perception and Approach towards Corporate Social Responsibility in SMEs: Case Study of Slovak and Czech Republic, PEFnet 2011 "European Scientific Conference of Ph.D. Students, Brno.

Ubrežiová, I., Stankovič, L., Mihalčová, B., \& Ubrežiová, A. (2013). Perception of Corporate Social Responsibility in Companies of Eastern Slovakia Region in 2009 and 2010. Acta Universitatis Agriculturae et Silviculturae Mendelianae Brunensis, 61 (7), 2903 -2010.

Ubrežiová, I., Kozáková, J., \& Malejčíková, A. (2015). Corporate Social Responsibility and Perception of Environmental Pillar in the Selected set of the Slovak Enterprises. Procedia of Economics and Finance, 34 (special issue), $542-549$. 


\section{General Information}

1. Number of employees in the company:
Micro (1 to 9)
Medium (50 to 249)
Small (10 to 49)
Large (More than 249)

2. Years of Operation of the Company:

$\square \quad$ Less than 1 year

5 to 9 years

1 to 4 years

More than 10 years

3. Region of Operation:

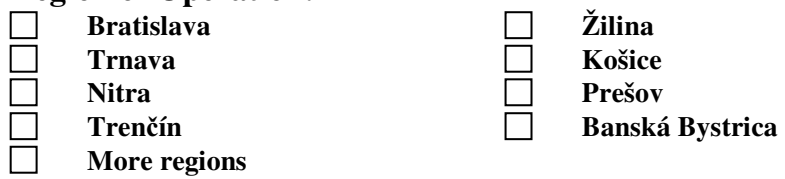

4. Ownership Structure of the Company:
Solely Slovak owner
Subsidy of MNE
Slovak owner with foreign investor
Solely foreign owner

5. Legal form of the Company: (please specify)

6. Financial Situation of the Company in Last Three Years:

$\begin{array}{ll}\begin{array}{l}\text { Very good } \\ \text { Above average } \\ \text { Average }\end{array} & \square \quad \begin{array}{l}\text { Below average } \\ \text { Getting worse }\end{array} \\ \square & \square\end{array}$

\section{CSR and its Implementation Within the Company:}

7. Are you familiar with the term CSR?

$\square$ Yes $\square \quad$ No

8. Has your company defined strategy (in writing or other form)?
$\square \quad$ Yes
No

9. Has your company defined mission and vision?
$\square \quad$ Yes
$\square \quad$ No

10. Please, indicate the extent to which you agree/disagree with following statements:

"Our company is a socially responsible company."

Strongly disagree $\quad 1 \square \quad 2 \square \quad 3 \square \quad 4 \square \quad 5 \square \quad$ Strongly agree

"CSR policy is closely related to the strategy of the company."

Strongly disagree $\quad 1 \square \quad 2 \square \quad 3 \square \quad 4 \square \quad 5 \square \quad$ Strongly agree

11. Is the company certified according to standards ISO, EMA, etc.? (e.g. ISO 9000, ISO

$14000, \ldots)$

$\square$ Yes

No, but the company is considering to obtain certification in the future 
12. If yes, please mark, which certification did you obtain/are planning to obtain in the future: (if no, continue to next question)

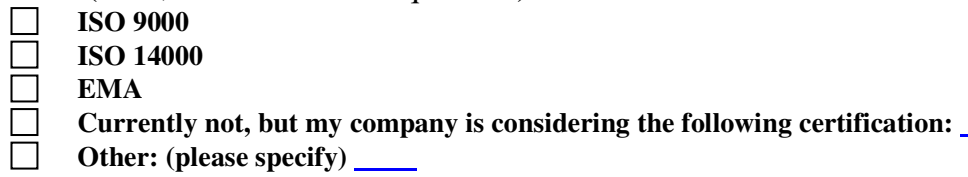

\section{Management of CSR}

13. Who is responsible for CSR within your company? (job title, department): (if such person/department does not exist, please write "no one")

14. If there is a person/department devoted to management of CSR, please indicator, how long this position/department is existing.

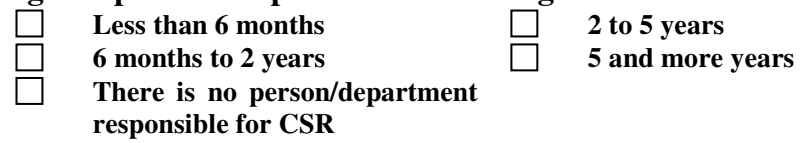

15. Please, indicate, to what extent each of the following factors motivates the company to undertake CSR activities

\begin{tabular}{|l|c|c|c|}
\hline \multicolumn{1}{|c}{ Did not motivate at all motivated } \\
\hline Ethical and moral reasons
\end{tabular}

Other factor: (please specify)

16. Please, indicate which from the following factors do you consider as main barriers to further/begin with CSR activities:

(more answers allowed)

$\square \quad$ Lack of knowledge

$\square \quad$ Lack of resources

$\square \quad$ Lack of legislation dealing with CSR

$\square \quad$ Weak motivation of employees

$\square \quad$ Lack of human resources

$\square \quad$ Lack of time

$\square \quad$ It is not important for the company

Other: (please specify) 


\section{$\underline{\text { IV. Environmental Pillar }}$}

17. Please, indicate to what extent the company is concerned with following activities:

\begin{tabular}{|c|c|c|c|c|c|}
\multicolumn{7}{c}{$\begin{array}{c}\text { Not at all } \\
\text { To great } \\
\text { extent }\end{array}$} \\
\hline Recycling & \multicolumn{1}{c}{$\mathbf{3}$} & $\square$ & $\square$ & $\square$ & $\square$ \\
\hline Waste reduction & $\square$ & $\square$ & $\square$ & $\square$ & $\square$ \\
\hline Saving the energy & $\square$ & $\square$ & $\square$ & $\square$ & $\square$ \\
\hline Saving the water & $\square$ & $\square$ & $\square$ & $\square$ & $\square$ \\
\hline $\begin{array}{c}\text { Environmentally friendly work } \\
\text { processes }\end{array}$ & $\square$ & $\square$ & $\square$ & $\square$ & $\square$ \\
\hline $\begin{array}{c}\text { Optimizing the transportation } \\
\text { Increase employees' knowledge } \\
\text { about environmental protection }\end{array}$ & $\square$ & $\square$ & $\square$ & $\square$ & $\square$ \\
\hline $\begin{array}{c}\text { Mutual cooperation with other } \\
\text { subjects }\end{array}$ & $\square$ & $\square$ & $\square$ & $\square$ & $\square$ \\
\hline $\begin{array}{c}\text { Purchase of machinery and } \\
\text { equipment friendly to environment }\end{array}$ & $\square$ & $\square$ & $\square$ & $\square$ & $\square$ \\
\hline
\end{tabular}

Please, describe any other activities or comments dealing with environmental pillar:

\section{Policy at the Workplace}

18. Please, indicate to what extent the company is concerned with following activities:

\begin{tabular}{|c|c|c|c|c|c|}
\multicolumn{2}{c}{ Not at all } \\
\begin{tabular}{|c|c|c|c|} 
Safety and protection of health at the \\
workplace
\end{tabular} & $\square$ & $\square$ & $\square$ & $\square$ & $\square$ \\
\hline $\begin{array}{c}\text { Development of real skills and long- } \\
\text { term carriers of employees }\end{array}$ & $\square$ & $\square$ & $\square$ & $\square$ & $\square$ \\
\hline $\begin{array}{c}\text { Reduction of discrimination in all } \\
\text { forms }\end{array}$ & $\square$ & $\square$ & $\square$ & $\square$ & $\square$ \\
\hline $\begin{array}{c}\text { Helping dismissed employees with } \\
\text { further carriers/their re-qualification }\end{array}$ & $\square$ & $\square$ & $\square$ & $\square$ & $\square$ \\
\hline $\begin{array}{c}\text { Work benefits (e.g. home office, } \\
\text { additional insurance, ...) }\end{array}$ & $\square$ & $\square$ & $\square$ & $\square$ & $\square$ \\
\hline $\begin{array}{c}\text { Work-life balance } \\
\text { Recruitment of physically and } \\
\text { mentally disabled }\end{array}$ & $\square$ & $\square$ & $\square$ & $\square$ & $\square$ \\
\hline $\begin{array}{c}\text { Communication of management with } \\
\text { employees }\end{array}$ & $\square$ & $\square$ & $\square$ & $\square$ & $\square$ \\
\hline $\begin{array}{c}\text { Anti-corruption and bribery } \\
\text { standards }\end{array}$ & $\square$ & $\square$ & $\square$ & $\square$ & $\square$ \\
\hline
\end{tabular}

Please, describe any other activities or comments dealing with policy at the workplace: 


\section{Policy Towards Community}

Please indicate, to what extent the company is concerned with following activities:

\begin{tabular}{|c|c|c|c|c|c|}
\hline \multicolumn{5}{|c|}{ Not at all } & \multirow{2}{*}{$\begin{array}{c}\text { To great } \\
\text { extent } \\
5 \\
\end{array}$} \\
\hline & & & & & \\
\hline Charity donations & $\square$ & $\square$ & $\square$ & $\square$ & $\square$ \\
\hline $\begin{array}{c}\text { Supporting the community in } \\
\text { organization of events (cultural, } \\
\text { sports, ...) }\end{array}$ & $\square$ & $\square$ & $\square$ & $\square$ & $\square$ \\
\hline $\begin{array}{c}\text { Cooperation with local community } \\
\text { (on projects, ...) }\end{array}$ & $\square$ & $\square$ & $\square$ & $\square$ & $\square$ \\
\hline $\begin{array}{l}\text { Purchasing goods and resources } \\
\text { from local suppliers }\end{array}$ & $\square$ & $\square$ & $\square$ & $\square$ & $\square$ \\
\hline
\end{tabular}

Please, describe any other activities or comments dealing with policy towards community:

\section{Economic Pillar}

Please indicate, to what extent the company is concerned with following activities:

\begin{tabular}{|c|c|c|c|c|c|}
\hline \multicolumn{5}{|c|}{ Not at all } & \multirow{2}{*}{$\begin{array}{c}\text { To great } \\
\text { extent } \\
5\end{array}$} \\
\hline & 1 & 2 & 3 & 4 & \\
\hline $\begin{array}{c}\text { Protection of intellectual property } \\
\text { rights }\end{array}$ & $\square$ & $\square$ & $\square$ & $\square$ & $\square$ \\
\hline $\begin{array}{c}\text { Providing information to } \\
\text { stakeholders (consumers, suppliers, } \\
\ldots \text {...) }\end{array}$ & $\square$ & $\square$ & $\square$ & $\square$ & $\square$ \\
\hline Transparency of company's activities & $\square$ & $\square$ & $\square$ & $\square$ & $\square$ \\
\hline Fair trade & $\square$ & $\square$ & $\square$ & $\square$ & $\square$ \\
\hline $\begin{array}{l}\text { Relations with shareholders, } \\
\text { suppliers and business partners }\end{array}$ & $\square$ & $\square$ & $\square$ & $\square$ & $\square$ \\
\hline
\end{tabular}

Please, describe any other activities or comments dealing with economic pillar:

\section{Concluding Questions About CSR}

Please indicate, to what extent do you agree/disagree with following statement:

"The CSR activities within the company are conducted on a regular basis."

$$
\text { Strongly disagree } \quad 1 \square \quad 2 \square \quad 3 \square \quad 4 \square \quad 5 \square \quad \text { Strongly agree }
$$

Has the company developed strategy dealing with social and environmental activities (in other words - CSR strategy)?
$\square \quad$ Yes
No

Does the company measure the activity within these two areas?
$\square$ Yes
$\square \quad$ No
$\square \quad$ No, but the company is planning to do so in the future

Is the company planning to increase/decrease social and environmental activities in the next 3 years?
Yes, increase
No, decrease
Same level 